Tersedia online di: http://ejournal-balitbang.kkp.go.id/index.php/jra

\title{
VAKSIN KERING BEKU SEL UTUH BAKTERI Aeromonas hydrophila UNTUK PENCEGAHAN PENYAKIT MOTILE AEROMONADS SEPTICEMIA PADA IKAN LELE, NILA, DAN GURAMI
}

\author{
Desy Sugiani\#, Taukhid, Uni Purwaningsih, dan Angela Mariana Lusiastuti \\ Balai Penelitian dan Pengembangan Budidaya Air Tawar \\ Jl. Sempur No. 1, Bogor 16129 \\ (Naskah diterima: 11 Januari 2018; Revisi final: 8 Mei 2018; Disetujui publikasi: 8 Mei 2018)
}

\begin{abstract}
ABSTRAK
Vaksinasi merupakan salah satu cara yang efektif untuk pencegahan penyakit infeksius pada budidaya ikan. Produk vaksin yang tersedia saat ini masih berbasis produk cair (water based vaccines), yang memiliki kekurangan dalam stabilitas produk yang tidak tahan lama jika disimpan dalam suhu ruang dan keterbatasan dalam tranportasi. Penelitian ini bertujuan untuk mengembangkan metode preparasi sediaan produk vaksin sel utuh Aeromonas hydrophila dalam bentuk kering beku (freeze dried) untuk pengendalian penyakit pada ikan lele (Clarias sp.), nila (Oreochromisniloticus), dan gurami (Osphronemus gouramy). Penelitian dilakukan dengan membuat produk vaksin kering beku pada suhu $-100^{\circ} \mathrm{C}$, uji mutu, uji keamanan, dan uji efikasi. Penelitian ini telah menghasilkan produk vaksin kering beku yang aman diaplikasikan pada ikan lele, nila, dan gurami, serta dapat menginduksi peningkatan level titer antibodi. Sediaan vaksin sel utuh A. hydrophila dengan metode kering beku dapat mereduksi berat produk vaksin cair 100 g menjadi serbuk sebesar 4,2 g. Efikasi vaksin menghasilkan tingkat sintasan relatif (RPS/relative percent survival) pada ikan nila (Oreochromis niloticus) 45,83\% ikan lele (Clarias sp.) 70\% dan ikan gurami (Osphronemus gouramy) 31,67\% Vaksin kering beku sel utuh bakteri Aeromonas hydrophila paling efektif diberikan pada ikan lele untuk mencegah penyakit Motile Aeromonads Septicemia.
\end{abstract}

KATA KUNCl: vaksin kering beku; Aeromonas hydrophila; lele; nila; gurami; RPS

ABSTRACT: The efficacy of freeze dried whole cell vaccine Aeromonas hydrophila against motile aeromonads septicemia on catfish, tilapia, and gouramy. By: Desy Sugiani, Taukhid, Uni Purwaningsih, and Angela Mariana Lusiastuti

Vaccination is one of the most effectivemethods to prevent disease outbreaks and distribution in aquaculture. Commercial fish vaccine products are mainly available in liquid-based products (water-based vaccines), which have several limitations such as stability issues of the products (durability) when stored at room temperature, bulky packaging, and transportation complexity during distribution. This study aimed to develop a method of vaccine preparation using the freeze-dried method as part of the management control of Aeromonads septicemia disease in freshwater aquaculture. The study consisted of several stages: the first stage was the production of freeze-dried Aeromonas hydrophila vaccine product at $-100^{\circ} \mathrm{C}$. The second stage was vaccine quality test followed by the third stage which was vaccine efficacy test. This research produced frozen dried vaccine products that were considered safe to be applied to catfish, tilapia, and gourami, and could increase the antibody titer. The formation of the whole cell vaccine of $\mathbf{A}$. hydrophila using the freeze-dried method could reduce the weight of the liquid form of the vaccine product from $100 \mathrm{~g}$ to a powder weighing only $4.2 \mathrm{~g}$. The results of the vaccine efficacy test showed the relative percent survivals (RPSs) of Clarias sp., Oreochromis niloticus and Osphronemus gouramy were $70 \% 45.83 \%$ and $31.67 \%$ respectively. Freeze dried vaccine of whole cells Aeromonas hydrophila are most effective in catfish to prevent M otile Aeromanads Septicemia.

KEYWORDS: freeze-dried vaccine; Aeromonas hydrophila; Oreochromis niloticus; Clarias sp.; Osphronemus gouramy; RPS

\footnotetext{
\# Korespondensi: Balai Riset Perikanan Budidaya Air Tawar dan

Penyuluhan Perikanan. Jl. Sempur No. 1, Bogor 16129,

Indonesia.

Tel. + 622518313200

E-mail: desysugiani@yahoo.co.id
} 


\section{PENDAHULUAN}

Aeromonas hydrophila adalah bakteri gram negatif yang menyebabkan hemorrhagic septicemia atau motile aeromonads septicemia (MAS) dengan mortalitas tinggi pada spesies ikan air tawar dan stadia pertumbuhan yang berbeda (Liu et al., 2015; Wang et al., 2015; Sugiani et al., 2012). Gejala MAS termasuk pembengkakan jaringan, luka merah, nekrosis, ulserasi, dan septikemia hemoragik. Spesies ikan yang paling sering terkena dampak MAS meliputi ikan nila, ikan lele, ikan mas (Salah et al., 2015), dan ikan gurami (Sugiani et al., 2016). Meskipun A. hydrophila biasanya dianggap sebagai patogen sekunder terkait dengan wabah penyakit, bisa juga muncul sebagai patogen utama yang menyebabkan wabah pada budidaya ikan dengan tingkat kematian tinggi dan kerugian ekonomi yang serius terhadap akuakultur.

Untuk mengendalikan MAS, ikan yang terinfeksi dapat diobati dengan antibiotik melalui pakan maupun perendaman. Namun, praktek ini mahal dan biasanya tidak efektif karena ikan sakit cenderung tidak mau makan. Selain itu, MAS yang disebabkan oleh A. hydrophila termasuk infeksi akut yang menyebabkan mortalitas dalam 24 jam (Pridgeon \& Klesius, 2011). Selanjutnya, hanya ada tiga antibiotik saat ini yang disetujui penggunaannya secara terbatas oleh pemerintah Indonesia berdasarkan Permen KP No. 52 Tahun 2014 di antaranya golongan tetrasiklina dengan nama zat aktif klortetrasiklina, oksitetrasiklina, tetrasiklina. Selain itu, ada juga golongan makrolida dengan zat aktif eritromisina, dan golongan kuinolon dengan nama zat aktif enrofloksasina. Meluasnya penggunaan antibiotik untuk mengobati penyakit bakteri dalam akuakultur telah menyebabkan berkembangnya resistensi antibiotik terhadap berbagai jenis patogen ikan di seluruh dunia. Oleh karena itu, metode pengendalian alternatif sangat dibutuhkan dalam industri akuakultur.

Vaksinasi telah terbukti menjadi strategi pencegahan penyakit yang efektif dengan kemampuan untuk mengurangi wabah penyakit (Pridgeon et al., 2012; Sugiani et al., 2013; 2015). Ada beberapa vaksin yang telah dikembangkan untuk melindungi ikan terhadap penyakit yang disebabkan oleh A. hydrophila yaitu vaksin inaktif dari bakteri yang dilemahkan dan vaksin sub-unit (Caipang et al., 2014). M eskipun vaksin suntik dapat mengembangkan kekebalan protektif untuk A. hydrophila (Dash et al., 2011; Sugiani et al., 2014), namun pengembangan aplikasi vaksin pada pembudidaya ikan di Indonesia kurang efektif sehingga memengaruhi tingkat keberhasilan kegiatan vaksinasi ikan.

Beberapa vaksin bakteri telah dikembangkan dan diuji coba secara eksperimental. Sebagian besar vaksin bakteri memberikan tanggap kebal pada inang terhadap uji tantang patogen. Meskipun sebagian besar vaksin bakteri terbukti efisien, upaya penelitian masih diperlukan untuk membuat vaksin yang benarbenar efektif untuk ikan. Pemahaman tentang mekanisme kekebalan ikan selama vaksinasi akan menghasilkan desain dan meto de vaksinasi yang lebih baik, yang pada akhirnya dapat menghasilkan kemampuan proteksi yang lebih tinggi bila terjadi infeksi bakteri di fasilitas akuakultur (Caipang et al., 2014).

Sediaan vaksin saat ini lebih banyak dalam bentuk cair, hal ini tentu saja menambah biaya kirim produk dan berimbas pada meningkatnya harga vaksin. Penyimpanan vaksin dalam bentuk cair biasanya hanya bertahan selama satu tahun dalam suhu $4^{\circ} \mathrm{C}$. Jika disimpan dalam suhu ruang disinyalir produk vaksin akan cepat rusak. Sugiani et al. (2016) melakukan survai ke pembudidaya dan diperoleh informasi bahwa jenis sediaan vaksin kering (powder) diminati pembudidaya untuk digunakan dalam aplikasi vaksinasi sama halnya dengan vaksin cair. Bakteri dapat dikeringkan pada suhu rendah (freeze dried) dengan dua metode, yaitu pengeringan semprot (spray drying) dan pengeringan vakum (vacuum drying) dengan tujuan untuk meningkatkan daya tahan dalam proses lama waktu penyimpanan (Chavez \& Ledeboer, 2007). Penelitian ini bertujuan untuk mengembangkan metode preparasi sediaan produk vaksin melalui metode kering beku (freeze dried) dengan pengeringan vakum untuk pengendalian penyakit ikan lele, nila, dan gurami.

\section{BAHAN DAN METODE}

\section{Isolat Bakteri dan Ikan Uji}

Bakteri yang digunakan sebagai sumber pembuatan vaksin (master seed) adalah isolat bakteri Aeromonas hydrophila AHL0905-2 yang dikultur pada media Tryptic Soy Agar (TSA). Ikan uji menggunakan ikan air tawar yaitu ikan nila (Oreochromis niloticus) berukuran $35 \pm 0,5 \mathrm{~g}$; ikan lele (Clarias sp.) berukuran $15 \pm 0,5 \mathrm{~g}$; dan ikan gurami (0. gouramy Lac.) berukuran $25 \pm 1,5 \mathrm{~g}$. Semua ikan yang digunakan sudah melewati masa aklimatisasi selama 14 hari.

\section{Preparasi Vaksin Kering Beku}

Preparasi vaksin stok A. hydrophila dengan metode tanam kering di media agar. Bakteri A. hydrophila hasil postulat koch diinokulasi dalam media TSA, dikultur secara merata di seluruh permukaan media agar, diinkubasi dalam inkubator selama \pm 24 jam pada suhu $27^{\circ} \mathrm{C}$. Koloni bakteri yang tumbuh dikoleksi menggunakan jarum ose dan dimasukkan ke dalam botol volume $150 \mathrm{~mL}$ yang berisi $100 \mathrm{~mL}$ larutan salin steril ( $\mathrm{NaCl} 0,845 \%$. Selanjutnya suspensi bakteri 
diinaktifasi dengan menambahkan NBF (neutral buffer formalin) $3 \%(v / v)$, melalui pengadukan selama \pm 6 jam. Pengukuran kepekatan suspensi stok vaksin menggunakan spektrofotometer pada panjang gelombang $660 \mathrm{~nm}$ dan dilakukan platting untuk mengetahui kepadatan sel (cell forming unit) (cfu). Stok vaksin yang telah diperoleh kemudian disimpan dalam freezer dengan suhu $-60^{\circ} \mathrm{C}$ selama \pm 24 jam. Stok vaksin beku dikeringkan dalam mesin pengering vakum pada suhu $-100^{\circ} \mathrm{C}$ (CoolSafe ${ }^{\mathrm{TM}}$ freeze dryer) selama 3648 jam. Setelah kering sempurna, vaksin disimpan dalam suhu $4^{\circ} \mathrm{C}$, sedangkan untuk penyimpanan jangka panjang vaksin disimpan dalam suhu $-20^{\circ} \mathrm{C}$.

\section{Uji Sterilitas dan Keamanan Vaksin}

Uji sterilisasi stok bakteri dilakukan dengan mengkultur sediaan vaksin dalam media TSA dan diinkubasi pada suhu $27^{\circ} \mathrm{C}$ selama 24 jam untuk mengetahui ada tidaknya bakteri yang tumbuh dari jenis A. hydrophila maupun bakteri kontaminan. Uji keamanan vaksin dilakukan pada setiap perlakuan masing-masing menggunakan ikan lele, nila, dan gurami sebanyak 100 ekor dengan tiga kali ulangan. Setiap ekor ikan disuntik intraperitoneal dengan 0,2 $\mathrm{mL}$ vaksin. Setelah tujuh hari pemeliharaan dilakukan reisolasi bakteri untuk mendeteksi $A$. hydrophila dari ikan perlakuan. Vaksin dikatakan aman jika hasil dari reisolasi tidak diperoleh bakteri aktif yang sama dengan isolat vaksin dan tidak terjadi kematian ikan pasca vaksinasi.

\section{Uji Efikasi Vaksin dan Uji Tantang}

Pengujian efikasi vaksin kering beku dilakukan pada tigajenis ikan yang berbeda (nila, lele, dan gurami) dengan tiga ulangan dan kontrol tanpa vaksin. Vaksin kering beku diencerkan menggunakan larutan salin steril ( $\mathrm{NaCl} 0,845 \%$ sebanyak $100 \mathrm{~mL}$, hingga suspensi terlarut sempurna. Setiap ekor ikan diinjeksi intraperitoneal dengan $0,2 \mathrm{~mL}$ suspensi vaksin. Pemeliharaan ikan setelah divaksin dilakukan selama 21 hari dan waktu uji tantang salama 14 hari. Uji tantang dengan menggunakan bakteri A. hydrophila virulen pada dosis $\mathrm{LD}_{50}\left(1 \times 10^{7} \mathrm{cfu} \mathrm{mL}^{-1}\right)$. Ikan diamati setiap minggu untuk gambaran hematologi dan diamati setiap hari untuk sintasan (SR), kemudian dihitung menjadi nilai relative percent survival (RPS) untuk menentukan efektivitas vaksinasi.

\section{HASIL DAN BAHASAN}

\section{Vaksin A. hydrophila Kering Beku}

Hasil produk vaksin kering beku sel utuh A. hydrophila disimpan dalam wadah tabung kaca volume $15 \mathrm{~mL}$ dilengkapi dengan penutup dan diisi sediaan vaksin sebanyak 5-7 $\mathrm{mL}$. Lama waktu pengeringan dengan kepadatan sel bakteri $3 \times 10^{11} \mathrm{cfu} \mathrm{mL}^{-1}$ adalah \pm 42 jam tanpa henti hingga diperoleh sediaan vaksin kering beku yang sempurna. Hasil sediaan vaksin kering beku $A$. hydrophila dari yang semula berbentuk cair dengan berat $100 \mathrm{~g}$ terdehidrasi menjadi serbuk berwarna putih kemerahan dengan berat 4,2 g. Vaksin dalam bentuk serbuk tersebut lebih mudah dalam pengemasan dan proses pengiriman. Menurut Toledo et al. (2010), bakteri yang dikeringkan dapat menghasilkan produk yang terdehidrasi dan stabil selama penyimpanan. Vaksin dalam bentuk kering yang telah terdehidrasi diharapkan akan lebih tahan lama jika dibandingkan dengan produk cair dan dapat disimpan pada suhu ruang untuk jangka waktu tertentu.

Serbuk vaksin kering beku yang dihasilkan dalam penelitian ini belum dapat terlarut sempurna ketika proses pengenceran kembali sebelum digunakan untuk perlakuan vaksinasi, diduga karena sel bakteri yang terlalu kering dan tidak terenkapsulasi sehingga menghambat proses kelarutan suspensi. Pembuatan sediaan vaksin kering beku selanjutnya dapat menggunakan filler untuk membantu daya larut dalam air. Chavez \& Ledeboer (2007) mengemukakan bahwa bakteri dapat dikeringkan pada suhu rendah (freeze dried) untuk meningkatkan masa waktu penyimpanan. Bakteri kering dapat bertahan selama lebih dari tiga bulan pada suhu $30^{\circ} \mathrm{C}$. Penambahan protein dan karbohidrat sebagai pembawa (filler) dapat menambah masa waktu penyimpanan dan efektivitasnya dapat dipertahankan optimal. Penggunaan protein kedelai dan maltodekstrin atau susu skim dan gum acacia (gummi arabicum) dapat menghasilkan tingkat ketahanan bakteri kering terbaik selama penyimpanan.

\section{Sterilitas dan Keamanan Vaksin}

Hasil uji sterilitas pada sediaan vaksin kering beku setelah dilakukan preparasi gores pada media triptone soya agar (TSA) dan platting cair pada media triptic soy broth (TSB) menunjukkan tidak ada bakteri yang tumbuh dari jenis $A$. hydrophila maupun bakteri kontaminan.

Hasil uji keamanan vaksin (Gambar 1) memperlihatkan bahwa ikan nila, lele, dan gurami yang telah diinjeksi melalui intraperitoneal dengan sediaan vaksin kering beku tersebut menunjukkan tingkat kematian ikan hanya 0,33\%0,67\% selama tujuh hari pascainjeksi. Hasil pengamatan gerakan renang normal, nafsu makan stabil, dan tidak menunjukkan gejala peradangan ataupun tukak di area bekas injeksi. Gejala perubahan tingkah laku dan kerusakan di area bekas injeksi tersebut biasanya akan muncul jika ada efek toksik dari sediaan vaksin terhadap ikan (vaksin tidak aman). Selama masa uji keamanan vaksin tidak ada ikan yang menunjukkan gejala terinfeksi A. hydrophila. 


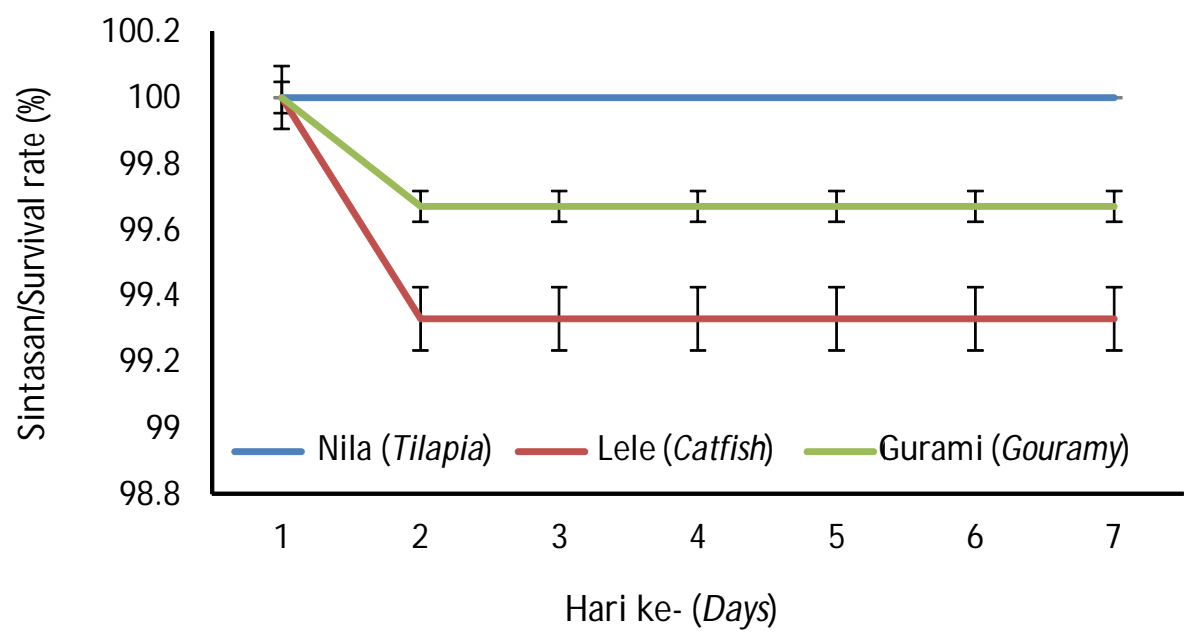

Gambar 1. Sintasan ikan nila, lele, dan gurami pada uji keamanan vaksin kering beku A. hydrophila.

Figure 1. Survival rates of tilapia, catfish, and gouramy on freeze-dried vaccine safety tests.

Hasil re-isolasi terhadap beberapa ikan pascavaksinasi juga tidak ditemukan adanya pertumbuhan bakteri yang sama dengan A. hydrophila. Dengan demikian vaksin kering beku yang dihasilkan pada pengujian ini dapat dinyatakan aman untuk ikan uji dan bersifat steril.

\section{Efikasi Vaksin}

Hasil titer antibodi menunjukkan bahwa perlakuan vaksin kering beku pada masa induksi vaksin sampai minggu ke-2 untuk kelompok ikan lele, nila, dan gurami ternyata lebih tinggi dalam membentuk respons imun dengan nilai 5-8 (log 2). Selanjutnya semua perlakuan mengalami penurunan nilai titer antibodi pada masa minggu ke-3 dan pada saat dilakukan uji tantang. Pada masa pemulihan yaitu dua minggu setelah uji tantang terlihat bahwa titer antibodi mengalami sedikit peningkatan yang kemudian diikuti adanya penurunan kembali (Gambar 2).

Titer antibodi mencerminkan kemampuan tubuh ikan terhadap infeksi bakteri melalui respons imun spesifik. Semakin tinggi nilai titer antibodi maka diharapkan kemampuan perlindungan terhadap infeksi juga menjadi tinggi. Antibodi yang beredar dalam sirkulasi darah akan menetralisasi molekul antifagositik dan eksotoksin lainnya yang diproduksi bakteri. Hasil penelitian terhadap respons humoral pada nila merah terhadap A. hydrophila yang diinaktivasi dengan formalin dan diberikan dengan injeksi intraperitoneal dapat menginduksi titer antibodi pada $925,87 \pm 467,92$ dan $4.983,47 \pm 1.832,74$ masingmasing pada respons imun primer dan sekunder (Prasad \& Areechon, 2010).
Ikan dapat membentuk pertahanan diri apabila terjadi suatu serangan patogen atau benda asing. Respons imun ini bersifat alami yang melibatkan sirkulasi dan perbaikan jaringan melalui respons fagosit granulosit (neutrofil dan eosinofil sel granular) monosit, dan sel makrofag. Respons imun alami ini hanya dapat bertahan dan berfungsi dengan baik pada beberapa hari atau minggu setelah adanya invasi bakteri ke dalam tubuh dan berfungsi sebagai respons imun anti-infeksi fase awal. Caruso et al. (2002) mengemukakan bahwa selama infeksi bakteri sedang berlangsung, adanya respons pertahanan ikan ditandai dengan banyaknya leukosit yang ditransfer sehingga akan nampak adanya peningkatan jumlah leukosit dalam darah yang berfungsi untuk mengeliminasi serangan bakteri.

Jumlah monosit, neutrofil, dan limfosit mengalami fluktuasi membentuk suatu homeostasi total leukosit dengan rata-rata terlihat adanya peningkatan jumlah limfosit dan monosit, serta adanya penurunan jumlah neutrofil jika dibandingkan dengan kontrol (Gambar $3,4,5)$.

Hal ini menunjukkan adanya aktivitas pertahanan non-spesifik dari ikan berupa peningkatan monosit darah yang berfungsi sebagai sel fagosit (makrofag) yang akan memfagositosis antigen bakteri dalam tubuh ikan. Peningkatan jumlah limfosit menunjukkan bahwa ada aktivitas pertahanan selular spesifik yang memungkinkan adanya pembentukan antibodi atau memori pada ikan yang dapat bertahan dari infeksi A. hydrophila.

Bailonea et al. (2010) memperoleh hasil bahwa vaksinasi polivalen (Aeromonas hydrophila, Pseudomo- 


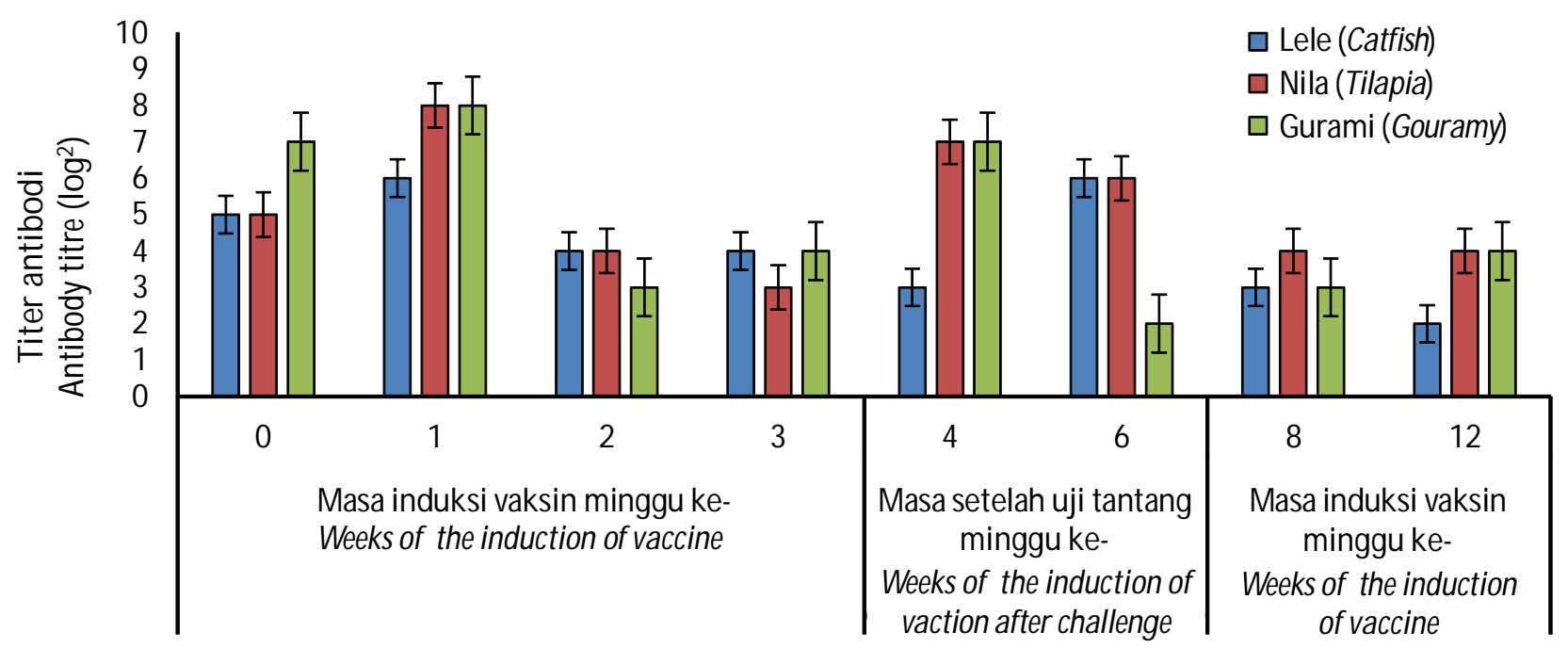

Waktu pengamatan (Observation time)

Gambar 2. Titer antibodi ikan lele, nila, dan gurami pasca vaksinasi dengan vaksin kering beku dan setelah uji tantang dengan A. hydrophila.

Figure 2. Titer antibodies of catfish, tilapia, and gouramy post vaccination using freeze-dried vaccine and after challenge test with $\mathbf{A}$. hydrophila.

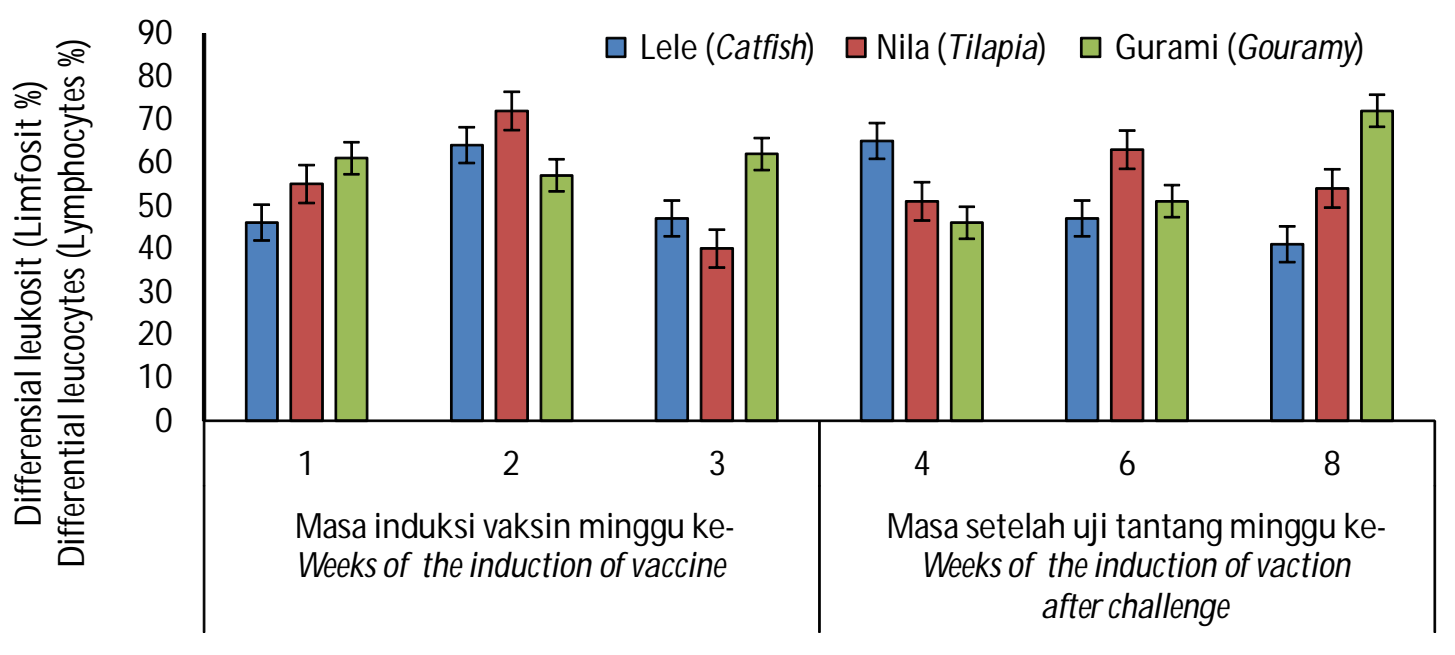

Waktu pengamatan (Observation time)

Gambar 3. Keragaan total limfosit pada ikan lele, nila, dan gurami selama vaksinasi dengan vaksin kering beku dan setelah uji tantang dengan A. hydrophila.

Figure 3. Performance of total lymphocytes of catfish, tilapia, and gouramy during vaccination using freeze-dried vaccine and after challenge test with $\mathbf{A}$. hydrophila. 


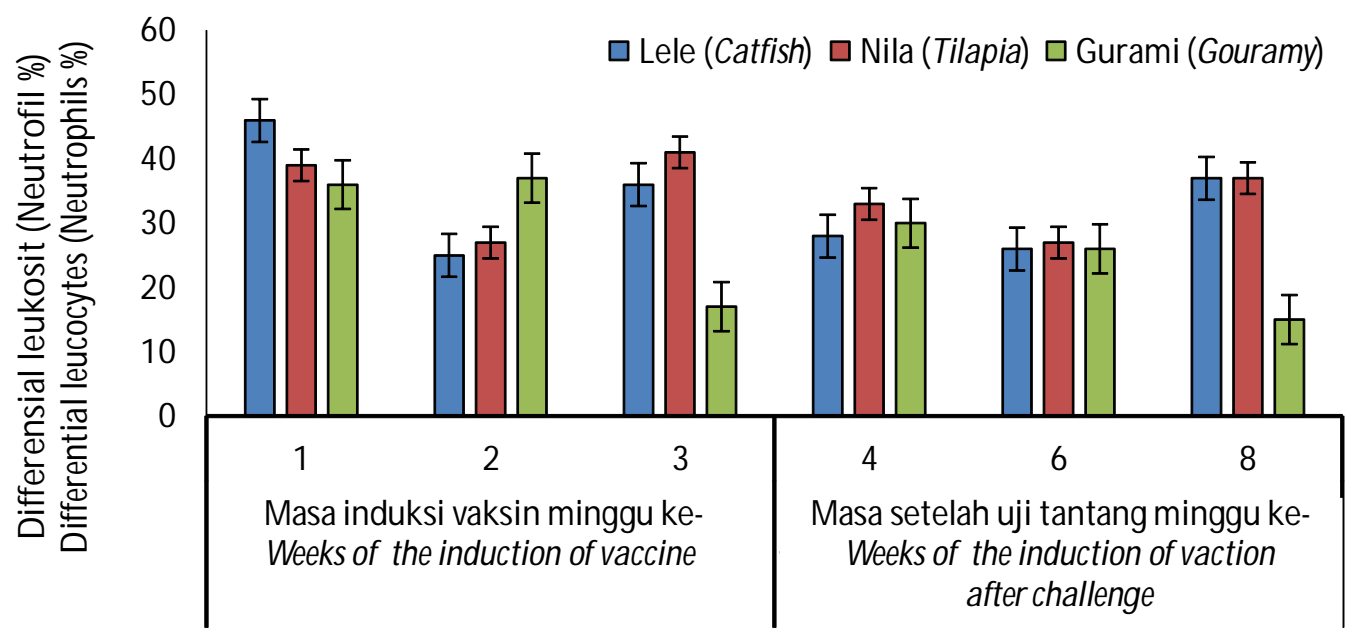

Waktu pengamatan (Observation ime)

Gambar 4. Keragaan total neutrofil pada ikan lele, nila, dan gurami selama vaksinasi dengan vaksin kering beku dan setelah uji tantang dengan A. hydrophila.

Figure 4. Performance of total neutrophils of catfish, tilapia, and gouramy during vaccination freeze-dried vaccine and after challenge test with $\mathbf{A}$. hydrophila.

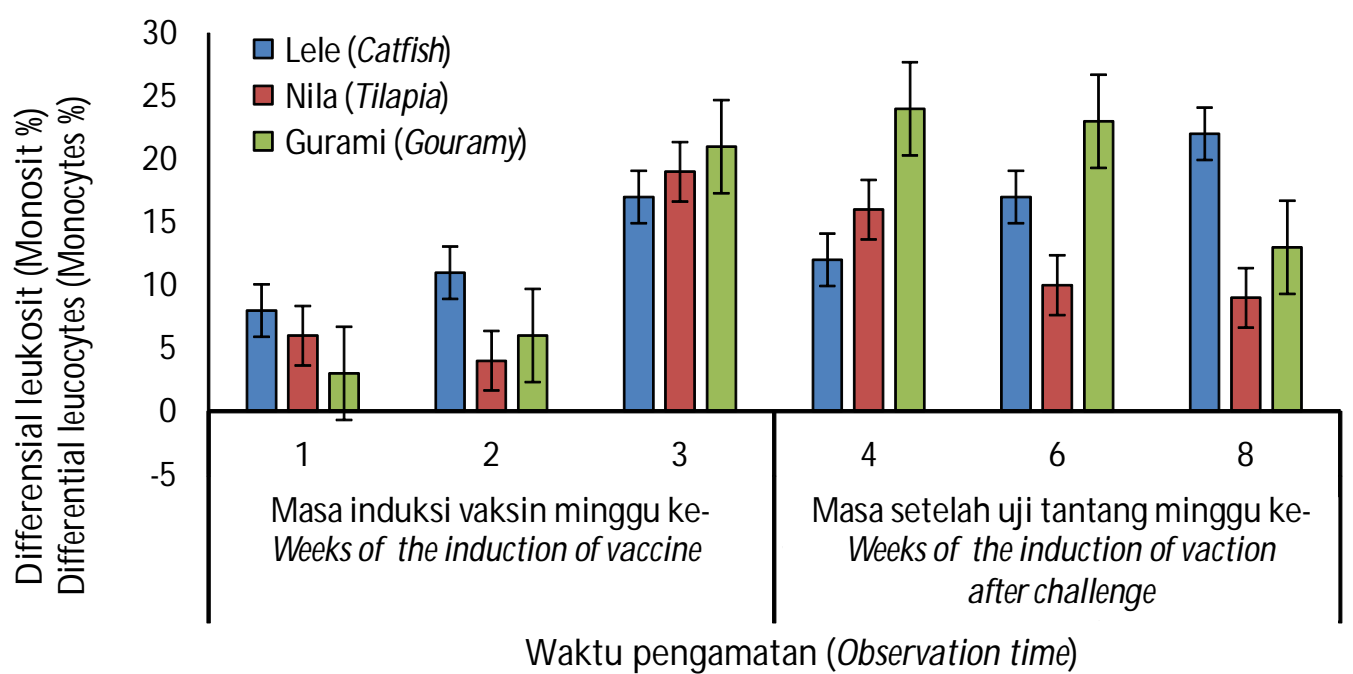

Gambar 5. Keragaan total monosit pada ikan lele, nila, dan gurami selama vaksinasi dengan vaksin kering beku dan setelah uji tantang dengan $\mathrm{A}$. hydrophila.

Figure 5. Performance of total monocytes of catfish, tilapia, and gouramy during vaccination freeze-dried vaccine and after challenge test with $\mathbf{A}$. hydrophila.

nas aeruginosa, dan Enterococcus durans) dapat memengaruhi respons aglutinasi hematologi dan serum pada ikan nila yang ditantang dengan Aeromonas hydrophila dengan dua dosis; $1 \times 10^{4} \mathrm{cfu} \mathrm{mL}^{-1}$ dan $1 \times$

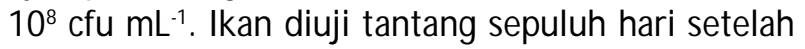
vaksinasi secara intraperitoneal dengan $A$. hydrophila $\mathrm{LD}_{50}-96 \mathrm{jam}\left(1 \times 10^{7} \mathrm{cfu} \mathrm{mL}^{-1}\right)$. Sebelum dan sesudah uji tantang, jumlah total leukosit dan jumlah limfosit menunjukkan nilai tertinggi pada ikan yang divaksinasi. Penelitian tersebut juga menunjukkan bahwa 10 hari setelah imunisasi terjadi peningkatan eritrosit, leukosit, trombosit, dan produksi limfosit dalam darah.

Rata-rata kematian ikan setelah uji tantang untuk ikan nila tervaksin $14,44 \%$ ikan nila kontrol $26,67 \%$ ikan lele tervaksin 10\% ikan lele kontrol 33,33\% ikan 


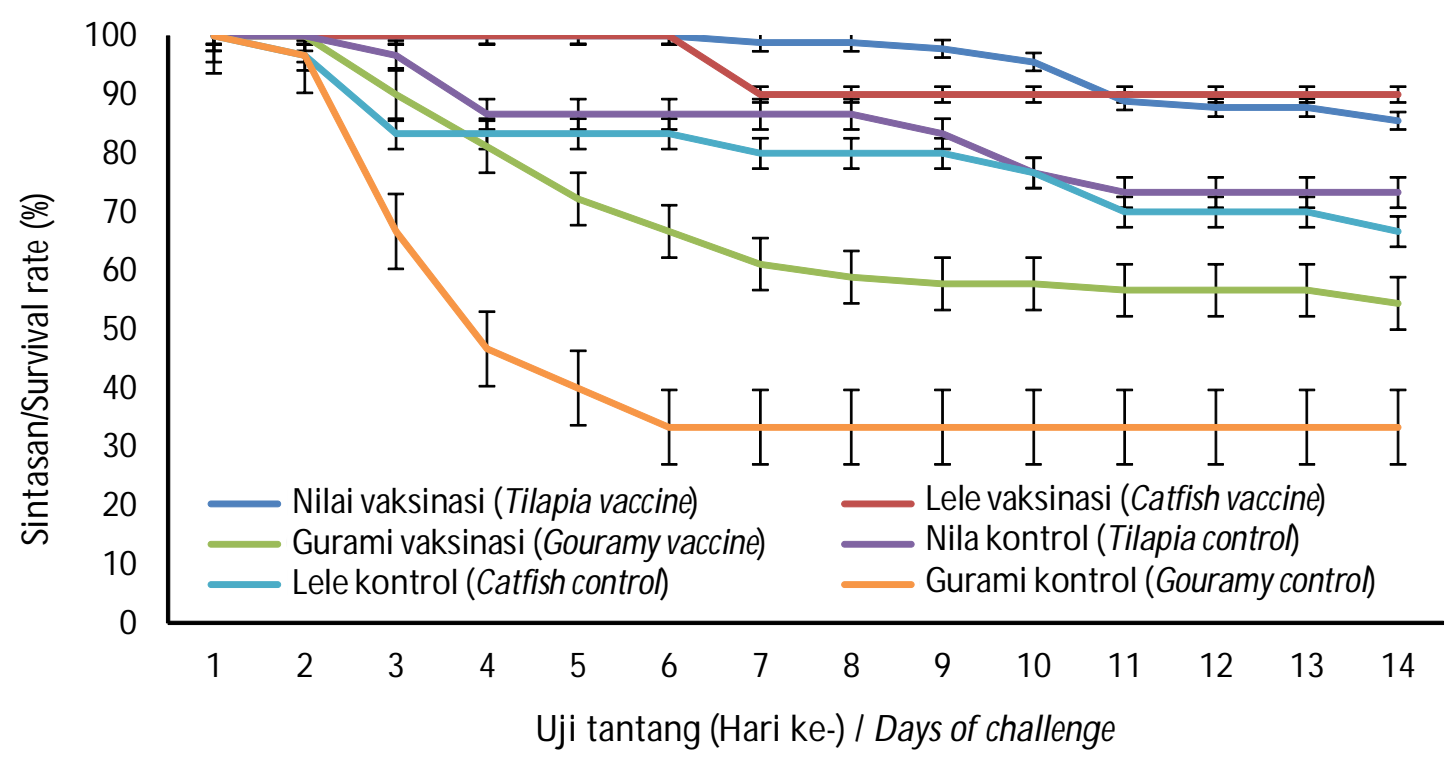

Gambar 6. Sintasan ikan nila, lele, dan gurami pasca uji tantang dengan A. hydrophila.

Figure 6 . Survival rate of tilapia, catfish, and gouramy after challenge test with $\mathbf{A}$. hydrophila.

gurami tervaksin $45,56 \%$ dan ikan gurami kontrol 66,67\% Hasil tersebut memperlihatkan adanya perbedaan kematian ikan sebesar $12,23 \%$ untuk kelompok ikan nila; 23,33\%untuk kelompok ikan lele; dan $21,11 \%$ untuk kelompok ikan gurami. Sintasan tertinggi diperoleh kelompok ikan nila dengan vaksinasi dan yang terendah adalah kelompok ikan gurami tanpa vaksin. Gambar 6 memperlihatkan bahwa kelompok perlakuan vaksin ikan nila, lele, dan gurami setelah diuji tantang dengan bakteri homolog berdasarkan jenis vaksin yang diberikan memiliki sintasan yang lebih tinggi jika dibandingkan dengan tanpa vaksinasi.

Nilai RPS ikan nila, lele, dan gurami pasca uji tantang menunjukkan hasil yang berbeda nyata (Tabel 1). Nilai RPS tertinggi (70\%) didapat dari perlakuan vaksin kering beku $\mathrm{A}$. hydrophila yang diberikan pada ikan lele dan diuji tantang oleh bakteri tunggal A. hydrophila homolog. Tingkat sintasan relatif (RPS) ikan nila yang divaksinasi menggunakan vaksin A. hydrophila yang diinaktivasi dengan formalin $(0,3 \%)$ setelah uji tantang adalah 49,99-66,66\% pada 6-10 minggu pascavaksinasi (Salah et al., 2015).

Persyaratan dari Kementerian Kelautan dan Perikanan bahwa nilai RPS untuk produk vaksin ikan yang dapat dikatakan baik dan dapat diedarkan ke pembudidaya adalah yang memiliki RPS > 50\% akan tetapi nilai RPS pada ikan nila $(45,83 \%$ dan gurami $(31,67 \%)$ masih rendah, capaian nilai RPS ini masih dapat ditingkatkan lagi dengan cara pembuatan produk vaksin menggunakan teknologi kering beku dengan memberikan tambahan perlakuan enkapsulasi pada sel

Tabel 1. Nilai sintasan relatif (RPS) ikan nila, lele, dan gurami pascavaksinasi dengan vaksin kering beku $A$. hydrophila

Table 1. Relative percent survival (RPS) value of tilapia, catfish, and gouramy post vaccination with freeze dried vaccine $\mathbf{A}$. hydrophila

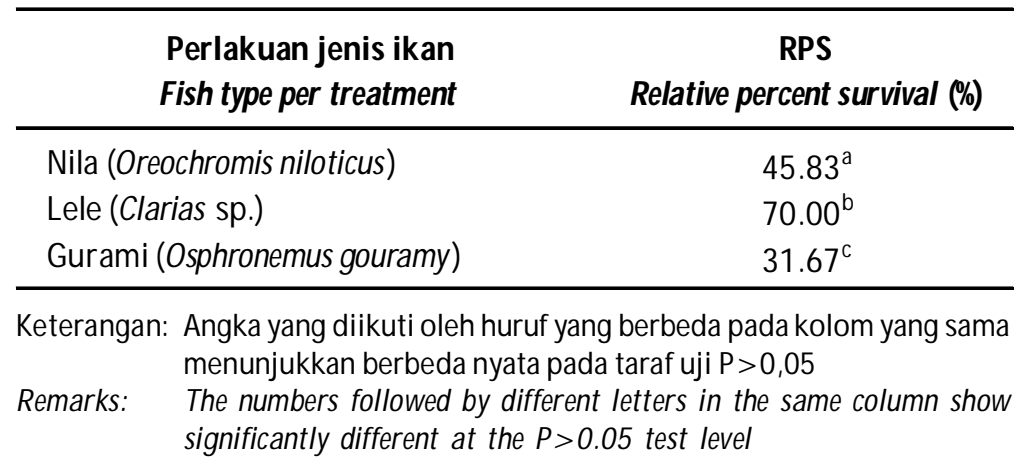


bakteri sebelum dilakukan proses pengeringan untuk melindungi sel bakteri dan untuk meningkatkan tingkat kelarutan produk, dan dibuat dalam sediaan multivalen. Sediaan vaksin dalam bentuk bivalen atau polivalen akan lebih meningkatkan RPS ikan dibandingkan dengan vaksin monovalen dalam melindungi ikan dari serangan infeksi tunggal maupun ko-infeksi (Sugiani et al., 2013; 2015).

Hasil penelitian pencegahan penyakit Streptococcosis akibat infeksi Streptococcus iniae pada nila merah (Oreochromis niloticus $x$ 0. mossambicus) menggunakan vaksin bakteri yang diinaktivasi formalin dengan perlakuan $1 \%$ vaksin kering beku yang dicampur pakan komersil yang diberikan secara oral menunjukkan hasil titer antibodi pada minggu ke-1 $(0,70 \pm 0,17)$ dan minggu ke-4 $(0,40 \pm 0,46)$. Kematian ikan selama masa induksi vaksin $9,75 \%$ dengan nilai persentase sintasan relatif (RPS) sebesar 41,46\%(Suanyuk \& Itsaro, 2011).

Penggunaan vaksin kering beku pada ikan salmon untuk penyakit furunkulosis memperlihatkan nilai persentase sintasan relatif (RPS) sebesar 70\%100\% pada aplikasi lapang, akan tetapi nilai RPS turun lebih rendah 30\%-40\% setelah diuji tantang secara eksperimental. Formulasi vaksin kering beku telah diuji kemampuannya dan dapat memberikan respons yang baik untuk proliferasi limfosit dan produksi antibodi. Vaksin kering beku memiliki masa simpan yang lebih panjang dengan potensi yang sama seperti bakteri yang baru tumbuh, menunjukkan bahwa potensi tersebut ada untuk vaksin hidup yang layak diproduksi untuk digunakan dalam akuakultur (Marsden et al., 1998).

\section{KESIMPULAN}

Sediaan vaksin sel utuh $A$. hydrophila dengan metode kering beku dapat mereduksi berat produk vaksin cair $100 \mathrm{~g}$ menjadi serbuk sebesar 4,2 g. Efikasi vaksin menghasilkan tingkat sintasan relatif (RPS/relative percent survival) pada ikan nila (Oreochromis niloticus) 45,83\% ikan lele (Clarias sp.) $70 \%$ dan ikan gurami (Osphronemus gouramy) 31,67\%

\section{UCAPAN TERIMA KASIH}

Penelitian ini telah terlaksana dengan sumber dana dari DIPA BPPBAT T.A. 2016, Kementerian Kelautan dan Perikanan dengan judul "Preparasi sediaan vaksin melalui enkapsulasi dan freeze dried untuk pengendalian penyakit ikan". Penul is mengucapkan terima kasih atas kerja sama dalam pelaksanaan kegiatan penelitian kepada Bapak Setiadi, Edy Farid Wadjdy, Ahmad Wahyudi, dan Johan Afandi.

\section{DAFTAR ACUAN}

Bailonea, R.L., Martinsa, M.L., Mourinoa, J.L.P., Vieiraa, F.N., Pedrottia, F.S., Nunesa, G.C., \& Silvaa, B.C. (2010). Hematology and agglutination titer after polyvalent immunization and subsequent challenge with Aeromonas hydrophila in Nile tilapia (Oreochromis niloticus). Archivos de Medicina Veterinaria, 42, 221-227.

Caipang, M.A.C., Lucanas, J.B., \& Lay-yag, C.M. (2014). Updates on the vaccination against bacterial diseases in tilapia, Oreochromisspp. and Asian seabass, Lates calcarifer. AACL Bioflux, 7(3), 184-193.

Caruso, D., Schlumberge, O., Dahm, C., \& Proteau, J.P. (2002). Plasma lysozyme levels in sheatfish Silurus glanis L. subjected to stress and experimental infection with Edwardsiella tarda. Aquaculture Research, 33, 999-1008.

Chavez, B.E., \& Ledeboer, A.M. (2007). Drying of probiotics: Optimization of formulation and process to enhance storage survival. Journal Drying Technology, 25(7-8), 1193-1201.

Dash, S., Das, S.K., Samal, J., Ojha, P.K., Patra, J.K., \& Thatoi, H. (2011). Dose dependence specific and non-specific immune responses of indian major carp (L. rohita ham) to intraperitoneal injection of formalin killed Aeromonas hydrophila whole cell vaccine. Veterinary Research Communications, 35, 541-552.

Liu, L., Gong, Y.-X., Zhu, B., Liu, G.-L., Wang, G.-X., \& Ling, F. (2015). Effect of a new recombinant Aeromonas hydrophila vaccine on the grass carp intestinal microbiota and correlations with immunological responses. Fish Shellfish Immunology, 45, 175-183.

Marsden, M.J., Vaughan, L.M., Fitzpatrick, R.M., Fosterm, T.J., \& Secombes, C.J. (1998). Potency testing of a live, genetically attenuated vaccine for salmonids. Vaccine, 16(11-12), 1087-1094.

Prasad, S., \& Areechon, N. (2010). Efficacy of formalin-killed Aeromonas hydrophila and Streptococcus sp. vaccine in red tilapia. Our Nature, 8, 231-240.

Pridgeon, J.W., Klesius, P.H., Mu, X., \& Song, L. (2011). $A n$ in vitro screening method to evaluate chemicals as potential chemotherapeutants to control Aeromonas hydrophila infection in channel catfish. Journal of Applied Microbiology, 111, 114-124.

Pridgeon, J.W., Yildirim-Aksoy, M., Klesius, P.H., Srivastava, K.K., \& Reddy, P.G. (2012). Attenuation of a virulent Aeromonas hydrophila with novobiocin and pathogenic characterization of the novobiocin-resistant strain. Journal of Applied Microbiology, 113, 1319-1328. 
Salah, M.A, Aqel, S.A., Arshad, H.R., \& Nashwa, M.A.A. (2015). The response of new-season nile tilapia to Aeromonas hydrophila vaccine. International Journal of clinical, 8(3), 4508-4514.

Suanyuk, N., \& Itsaro, A. (2011). Efficacy of inactivated Streptococcus iniae vaccine and protective effect of $b$-(1.3/1.6)-glucan on the effectiveness of vaccine in red tilapia Oreochromis niloticus $x 0$. mossambicus. Songklanakarin Journal of Science and Technology, 33(2), 143-149.

Sugiani, D., Sukenda, Harris, E., \& Lusiastuti, A.M. (2012). Pengaruh ko-infeksi bakteri Streptococcus agalactiae dengan Aeromonas hydrophila terhadap gambaran hematologi dan histopatologi ikan tilapia (Oreochromis niloticus). Jurnal Riset Akuakultur, 7(1), 85-91.

Sugiani, D., Sukenda, Harris, E., \& Lusiastuti, A.M. (2013). Vaksin ikan tilapia (Oreochromis niloticus) menggunakan vaksin monovalen dan bivalen untuk pencegahan penyakit motile aeromonas septicemia dan streptococcosis. Jurnal Riset Akuakultur, 8(2), 229-239.

Sugiani, D., Lusiastuti, A.M., Sukenda, \& Harris, E. (2014). Profil protein vaksin Aeromonas hydrophila dan Streptococcus agalactiae hasil inaktivasi dengan formalin: Diuji menggunakan sodium dodecyl sulphate-polyacrylamide gel electrophoresis. Jurnal Riset Akuakultur, 9(3), 449-461.

Sugiani, D., Aryati, Y., Mufidah, T., \& Purwaningsih, U. (2015). Efektivitas vaksin bivalen Aeromonas hydrophila dan Mycobacterium fortuitum untuk pencegahan infeksi penyakit pada ikan gurami (Osphronemus gouramy). Jurnal Riset Akuakultur, 10(4), 567-577.

Sugiani, D., Arifin, O.Z., Purwaningsih, U., \& Wadjdy, E.F. (2016). Uji aplikasi lapang vaksin bivalen hydrofortyVac dan vaksin monovalent (HydroVac dan MycofortyVac) pada benih ikan gurami (Osphronemus gouramy). Media Akuakultur, 11(2), 111-119.

Toledo, N., Ferrer, J., \& Bórquez, R. (2010). Drying and storage stability of a probiotic strain incorporated into a fish feed formulation. Journal Drying Technology, 28(40), 508-516.

Wang, N., Wu, Y., Pang, M., Liu, J., Lu, C., \& Liu, Y. (2015). Protective efficacy of recombinant hemolysin co-regulated protein (hcp) of Aeromonas hydrophila in common carp (Cyprinus carpio). Fish Shellfish Immunol., 46, 297-304. 